\title{
GIS METHODOLOGICAL APPROACH TO DEVELOPING AND FORMING A VISUAL IMAGE OF DOWNTOWN AMMAN
}

\author{
Al Fahmawee Emad Al Dein Hasan \\ Applied Science Private University, Faculty of Art and Design \\ Amman, Jordan, Shafa Badran \\ E-mail: e_fahmawee@asu.edu.jo
}

\begin{abstract}
Introduction: Amman's growth expansion was shaped by its topography (valleys and hills), which generated a special character and patterns of the urban form. The city was built on seven hills, which are connected by steep stairs that serve as pathways to the downtown core. The rapid urbanization caused by uncontrolled population growth, as well as random and unplanned formations that were far from following any kind of aesthetic, resulted in the expansion of the center towards the surrounding seven hills. The continuous intersection of these hills caused their boundaries to blur and melt. As a result of the intense transformation, which is causing the hills' appearance to become more uniform, their continuing overlap may completely destroy the unique character and imageability of downtown Amman. Methods: This research made use of topographical context analysis and the Geographical Information System (GIS) as well as its 3D modeling function to identify the optimal visibility and viewing angle when looking from the valley towards the hills and between the hills. Results and discussion: We identified the main vistas, i.e., highly significant views, which could subsequently be adopted as the locations for proposing landmark scenarios via 3D model GIS analysis. The projection process helped determine the significant views from the valley towards the hills and between the hills. Overall, three scenarios were proposed for the landmarks, out of which, the best one was chosen. It corresponds to the topographical analysis and the community needs, depends upon the local context and urban fabric, and is optimal for decision-making.
\end{abstract}

\section{Keywords}

Downtown, hills, visual image, topographical features, landmarks, line of sight analysis.

\section{Highlights}

- The spread of similar-looking residential buildings over the hills, without concern for the original character, has led to the depersonalization of the downtown environment.

- Visual differentiation between the hills, with no landmarks that distinguish any given hill from the others, has become extremely difficult.

- This research made use of the Geographical Information System (GIS) and its 3D modeling function for assessing and determining the sites for the proposed landmarks on each hill.

\section{Introduction}

Amman, the capital of Jordan, has emerged as a modern Arab city. The physical development of modern Amman has a time frame of only about 135 years. Ancient Amman was occupied by several sequential civilizations - Assyrians, Babylonians, Persians, Greeks, and Romans - but went into decline and was eventually deserted by the year 1400. In modern times, it experienced dramatic growth as a city of migrants, including the periodic influx of migrants from Palestine (1948, 1967, and 1973), Lebanon, and, most recently, Iraq (Ashour, 2016). More recently, some 170,000 Jordanians, including Palestinians who had obtained Jordanian citizenship, relocated to Amman from Kuwait and other countries of the Gulf region as a result of the 1990-1991 Gulf War (Al-Asad, 1997). Refugees have been attracted to the relative political stability of Jordan, and the city of Amman has provided a safe haven for populations in the region suffering from political displacement (Pilder, 2011).

Amman's growth expansion was shaped by its topography, specifically valleys and hills, which have given its urban form a special character and patterns. It has grown along seven successive hills, which formed the topography of early Amman (the downtown). The hills certainly are prominent city landmarks (Potter et al., 2009). They have their own character, inhabitants, and, to a certain extent, their own topography features. The tiny cubic houses, always visible on the slopes of the hills, have stripped the mountain of its original "skin" and settled in there as if they were an intrinsic part of the landscape. The downtown, which is located on these seven hills, naturally has developmental characteristics of its own. The buildings are connected by steep stairs that lead to the downtown core (valley). Gardening activity in the city is very low, insufficient for contributing to the creation of a favorable microclimate (Melnik, 2019).

Modern physical development began in a well- 
irrigated area at the confluence of several valleys, which evolved as the original downtown core of Amman (GAM, 2008). The residential areas spread gradually from a fertile valley at the downtown core of Amman to occupy the surrounding hills (ESCWA, 2005). These older residential areas borrow their names from the seven hills where they originally developed: Al Akhdar, Al Natheef, Al Ashraffiyyh, Al Taj, Al Qalaah, Al Luweibdah, and Amman hill. The division of these areas is based on a grid pattern, where the hills are physically separated but visually not related. The neighborhoods were once connected to the downtown core by steep stairs as pedestrian links.

The downtown core is the historic center of Amman, it "served as Amman's central business district with a mixed use pattern of religious institutions, residential neighborhoods, government offices, and commercial streets" (Ashour, 2016). The heritage urban form of the downtown core "is fine grain, small plots of low height structures spreading along the valley $<\ldots>$ Building more than four stories in the downtown valley would remove the strong shape" of the surrounding hills' profile (Ashour, 2016).

The downtown core has many significant individual buildings, sites, and objects, which are memorable to Amman's inhabitants and tourists due to their design. It also embraces four main historic sites with many heritage values. The Roman Citadel (Jabal al-Qala'ah), located on one of the hills, is one such site. Another very important monument is the Great Amphitheater at the bottom of the Fortress Mountain. The Al-Hussein mosque, built by king Abdallah I in 1924, is another excellent remaining example of Islamic architecture. The Nymphaeum is a notable landmark as well. According to ADTZSP (Amman Downtown Tourist Zone Sub-Project), despite the presence of ancient sites, such as the Roman Theater and the Citadel, tourists have been neglecting the downtown because of its inadequate promotion and lack of amenities and infrastructure for tourists (JICA, 2000).
The rapid urbanization caused by uncontrolled population growth, as well as random and unplanned formations that did not follow any aesthetic decisions, resulted in a shift from the longitudinal axial development to the gradual vertical multilayer structure, towards the surrounding seven hills. The spread of similar-looking residential buildings over the hills, plus the use of the same types of design techniques, materials and building density without concern for green elements and original character, led to the depersonalization of the urban environment. At the same time, a combination of unharmonized structures and textures also causes the observers to perceive disturbing chaos (Bostanci et al., 2006). In this case, a monotonous (aggressive) environment has been formed, causing emotional hunger, fatigue, and aggression among tourists and especially among residents (as shown in Fig. 1). Landmarks are highly important, as they are symbols that relate and represent the location's quality and the depth of its traditions and culture, with an enhanced significance over time (Clerici and Mironowicz, 2009).

The expansion of the center towards the surrounding hills, while forming a coherent fabric at the planning level, is actually scattered and chaotic at the aesthetic and visual level, which deprives the downtown of its imageability. The continuing overlap between the hills may completely destroy the unique local character, in the absence of a harmonious spatial composition with visual scenes that impress the viewer and form a unique image of the downtown. Residents and visitors find it hard to find their bearings and often get lost because there is no special character that would help tell each hill apart from the others. Instead, the cityscape melts in a single horizontal line, with no protruding architectural elements, causing confusion. Passini (1992) suggested that any object, even a fountain with a particular meaning, can be a landmark. Amman's Metropolitan Growth Plan did not offer any clear organizational and formative solutions
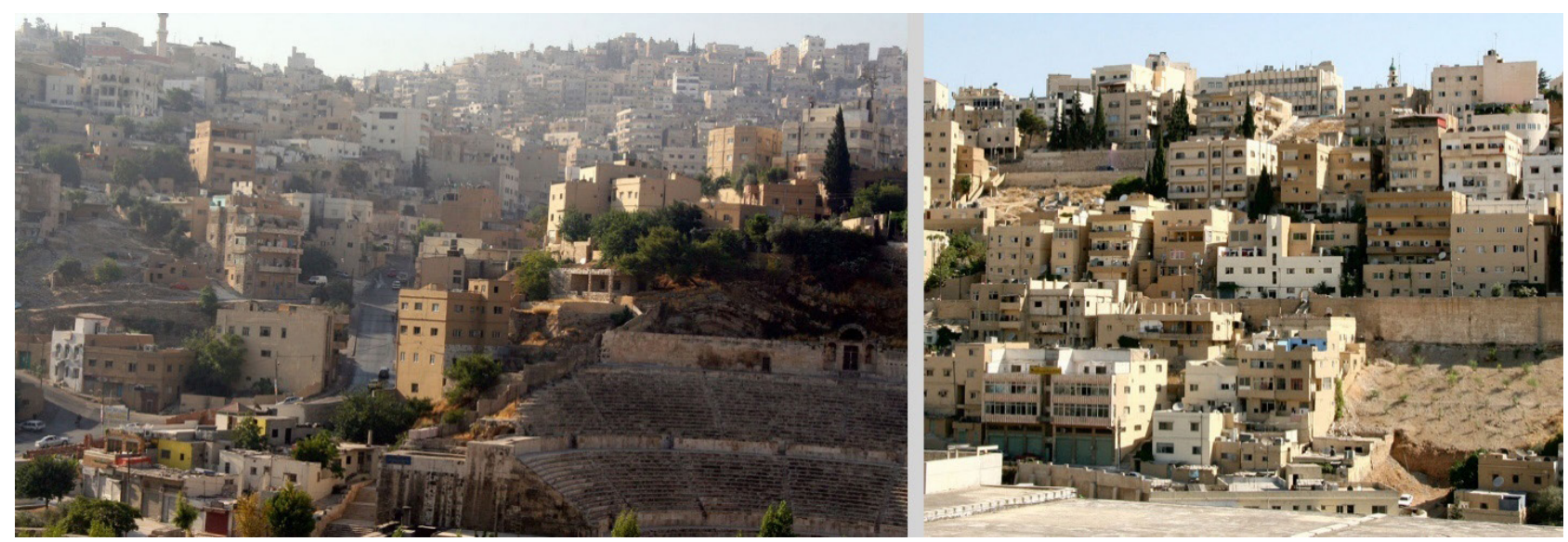

Figure 1. Overlap of the hills (on the left); view of the monotonous built form (on the right (source: the author) 
related to developing and improving the functional structure in the city center by linking it with its physical surroundings. The focus of the project was on the development of the longitudinal zone, as well as on building rehabilitation and the process of their expansion within the urban space in a longitudinal manner. The idea was to distribute buildings with a large floor density, like in most cities in the world (GAM, 2007). However, the downtown core and its hills, in terms of their spatial characteristics, heritage, and cultural, social, architectural, and historical functions, are not compatible with this proposition, which has negative urban repercussions, leading to the loss of the downtown core's and hills' perception and imageability.

The studies by K. Lynch focused on the identity and structure of city images. He defined "imageability" as "that quality in a physical object which gives it a high probability of evoking a strong image in any given observer" (Lynch, 1960). A city's image is important because it contributes to forming the observers' (or the inhabitants') perception, taste, and behaviors; as well as the language that the observers use and the range of notions that they possess about the environment around them (ZmudzinskaNowak, 2003). The visual image is intimately related to the mental image, which is retained in the observer's memory, thus helping generate environmental meaning during the evaluation of the city image and sense of place (Silva, 2004).

The preliminary objective of this study is to find a distinctive volumetric-spatial solution, namely a complex of landmarks based on the principles and patterns of architectural composition, through emphasizing the city's character and defining the boundaries of the downtown core and its correlation with the neighborhoods on the surrounding hills. The character of the downtown must be enhanced by focusing on preserving buildings with heritage value, protecting the urban form, improving the green zones in the valley, and especially by creating landmarks. Lynch defines a landmark as an element with distinctive spatial features, which are visible from many angles and distances, including over the tops of smaller elements, and can be used as radial reference to help people orientate or find their way in the surrounding environment (Lynch, 1960). The gradient topography in new development should be respected and the topography of the site should be enhanced through careful positioning of the physical structures (landmarks) and the use of the hill slope to create cityscape perception. The perception influences and helps the observer shape their mental image by way of keeping the attractive and important elements of the city in their mind (Atik et al., 2009). Global Mapper software offers several tools for qualitative and quantitative analysis of visual impact assessment. Terrain analysis is very useful

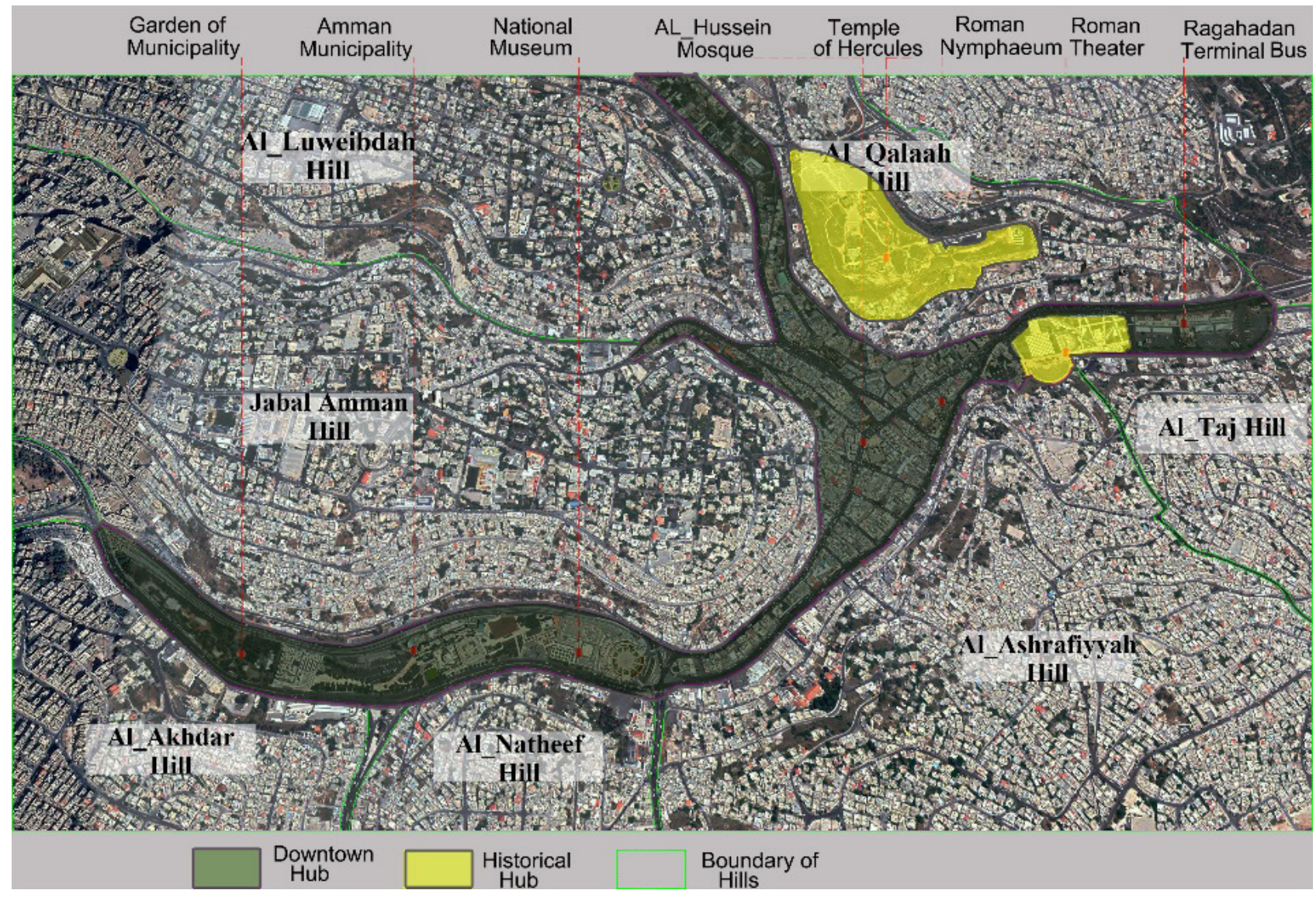

Figure 2. Boundaries of the study area (source: the author) 
in this regard. We used viewshed and line of sight analysis to identify the viewing angle and best visible area from the valley, which allowed us to determine the potential locations for the proposed landmarks on each hill, from designated viewer observation points.

\section{Methodology}

\subsection{Study area}

The study area includes the side slopes of the seven hills in Amman, overlooking the downtown core, as represented in Photo 1. The area extends from the Raghadan bus terminal to the Greater Amman Municipality, totaling 1840 donums. This area represents the origins of Amman and is considered a tourist attraction because it includes important historical sites, such as the Roman Amphitheater, the Citadel, the Al-Hussein mosque, and the Nymphaeum (as shown in Fig. 2).

\subsection{Topographical Context Analysis}

\subsubsection{Field survey}

This survey contributes to understanding the current urban conditions and assessing the significance of the built form. Finally, the survey elicited feedback from residents, visitors, and tourists regarding urban regeneration, new landmarks, and other general suggestions.

\subsubsection{Orthographic physical survey}

A physical survey was conducted for the downtown core and its surrounding hills. It briefly explains the different features and dynamism of the study areas, in addition to providing a series of digital orthoimages of the downtown core and the surrounding hills, for the initial visualization of the valley and its mutual relationship and links with the hills. The survey helped define the topography of various areas, including the distribution of green and vacant urban spaces, the surviving historic topographical features, the ways in which past functions have defined the existing morphology, the dominant building types, the presence of key historic buildings, as well as the construction materials, architectural styles, and specific features.

\subsubsection{Data collection (geoprocessing)}

We collected data on architectural categorization, land use and occupancy, and the hills' elevation, in addition to maps and drawings, through the Greater Amman Municipality and the Royal Geographic Center, using a Geographic Information System (GIS).

\subsection{Line of sight analysis and 3D projection}

The most vital stage in this study involved collecting data with the 3D visualizing and analytical function in the GIS for mapping, as well as analyzing and evaluating the prediction of newly proposed landmarks with sufficient location and elevation accuracy. Line of sight analysis in Global Mapper allows for calculating the visibility along the sight line from the observation point (valley) to the target object (hilltop). We configured the calculations along the selected path, using the path profile line of sight analysis program. A path along the valley was created, then several profiles perpendicular to the valley path (cross-sections) were formed. The spacing of the cross-sections along the path is $25 \mathrm{~m}$; the width is $1750 \mathrm{~m}$, forming 180 cross-sections along the valley path. This width of the cross-section was chosen to cover the largest area between the valley and the surrounding hills from top to top, for study purposes. The 3D visual representation is a combination of the digital terrain model, the orthoimage, and the three-dimensional features for the valley and the hills.

\subsection{Conceptualization of the landmark} scenario

Three designs were proposed for the landmarks on the hilltops, all of which were based on the topographic survey and the physical GIS analysis of the site, in addition to feedback from interviews with the local community regarding urban regeneration and the new landmarks. Each scenario offered a different approach, and all were based on global experiences.

\section{Results and Discussion}

\subsection{Topographical features}

The Amman downtown is dominated by its distinctive topography, specifically the basin of the valley and the surrounding hills. The Amman valley is surrounded by slopes with a $20 \%$ incline, which shape the downtown image and the nature of urban development along the valley's boundaries. The $30-40 \%$ slopes, located in some parts along the hillsides, hinder urban development and add to the overlap between the natural and urban fabric. Although early development began in the valleys, it soon climbed up the hills around the downtown to create a dense formation of monotonous built forms, which dominates the slopes. This led to overlaps between the hills, which became difficult to tell apart visually, with no landmarks that distinguish one hill from another. Gaps of open space at the top of the hills are almost nonexistent, as demonstrated in Fig. 3.

There is great variation in the incline of the valley and the surrounding hills, ranging from smooth slopes to steep cliffs, as highlighted in Table 1 below. Exposed slopes are an important visual feature of the surrounding hills. The remaining vegetation is also an important property, especially on the slopes. However, it is extremely vulnerable to urban growth. Poor management is threatening the remaining trees and urban development is threatening some of the most biologically diverse areas within the downtown. The difference in hill elevation is quite notable: $\mathrm{Al}$ Qalaah Hill is the lowest, with a height of $835 \mathrm{~m}$, while Al-Ashraffiyyh Hill is the tallest, with a height of $930 \mathrm{~m}$, as seen from the valley. The hill heights are demonstrated in Fig. 6. 
Table 1. Physical and topographical analysis of the Amman hills (source: the author). Elevation of the valley: $740 \mathrm{~m}$

\begin{tabular}{|c|c|c|c|c|c|c|c|c|c|c|}
\hline & Hill name & ${ }^{*}$ Elevation & $\begin{array}{l}\text { Topography } \\
\text { qualities }\end{array}$ & $\begin{array}{l}\text { Historical } \\
\text { value }\end{array}$ & $\begin{array}{l}\text { Heritage } \\
\text { value }\end{array}$ & $\begin{array}{l}\text { Land- } \\
\text { marks }\end{array}$ & $\begin{array}{l}\text { Vacant } \\
\text { lands }\end{array}$ & $\begin{array}{l}\text { Building } \\
\text { height }\end{array}$ & $\begin{array}{l}\text { Stairway path } \\
\text { Assessments }\end{array}$ & $\begin{array}{l}\text { Land use } \\
\text { (on the side } \\
\text { slopes) }\end{array}$ \\
\hline 1 & $\begin{array}{l}\text { Al Akhdar } \\
\text { Hill }\end{array}$ & $895 \mathrm{~m}$ & $\begin{array}{l}\text { Steep } \\
\text { slopes }\end{array}$ & - & - & - & $12 \%$ & $\begin{array}{l}2-4 \\
\text { floors }\end{array}$ & Problematic & Residential \\
\hline 2 & $\begin{array}{c}\text { Al Nadtheef } \\
\text { Hill }\end{array}$ & $840 \mathrm{~m}$ & $\begin{array}{l}\text { Steep } \\
\text { slopes }\end{array}$ & - & low & - & $10 \%$ & $\begin{array}{l}2-4 \\
\text { floors }\end{array}$ & Problematic & Residential \\
\hline 3 & $\begin{array}{c}\text { Al } \\
\text { Ashraffiyyh } \\
\text { Hill }\end{array}$ & $930 \mathrm{~m}$ & $\begin{array}{c}\text { Steep } \\
\text { slopes and } \\
\text { extremely } \\
\text { sculpted } \\
\text { terrain } \\
\end{array}$ & Low & medium & $\begin{array}{c}\text { Abu- } \\
\text { Darweesh } \\
\text { Mosque }\end{array}$ & $22 \%$ & $\begin{array}{l}2-4 \\
\text { floors }\end{array}$ & Problematic & Residential \\
\hline 4 & Al Taj Hill & $890 \mathrm{~m}$ & $\begin{array}{l}\text { Steep } \\
\text { slopes } \\
\text { and natural } \\
\text { caves }\end{array}$ & Low & low & - & $18 \%$ & $\begin{array}{l}2-4 \\
\text { floors }\end{array}$ & Good & Residential \\
\hline 5 & $\begin{array}{l}\text { Al Qalaah } \\
\text { Hill }\end{array}$ & $835 \mathrm{~m}$ & $\begin{array}{l}\text { Steep rock } \\
\text { face }\end{array}$ & High & high & $\begin{array}{c}\text { The } \\
\text { Citadel } \\
\text { Temple of } \\
\text { Hercules }\end{array}$ & $30 \%$ & $\begin{array}{l}2-6 \\
\text { floors }\end{array}$ & Problematic & $\begin{array}{l}\text { Minimal } \\
\text { public land } \\
\text { use }\end{array}$ \\
\hline 6 & $\begin{array}{c}\mathrm{Al} \\
\text { Luweibdah } \\
\text { Hill }\end{array}$ & $840 \mathrm{~m}$ & $\begin{array}{l}\text { Steep } \\
\text { slopes }\end{array}$ & Medium & high & $\begin{array}{c}\text { Al } \\
\text { Weibdah } \\
\text { church }\end{array}$ & $15 \%$ & $\begin{array}{l}2-5 \\
\text { floors }\end{array}$ & Good & $\begin{array}{c}\text { Residential } \\
\text { and cultural } \\
\text { heritage }\end{array}$ \\
\hline 7 & Amman Hill & $860 \mathrm{~m}$ & $\begin{array}{l}\text { Steep } \\
\text { stone cliffs }\end{array}$ & Low & high & - & $20 \%$ & $\begin{array}{l}2-6 \\
\text { floors }\end{array}$ & Good & $\begin{array}{c}\text { Residential } \\
\text { Minimal } \\
\text { public land } \\
\text { use }\end{array}$ \\
\hline
\end{tabular}

\subsection{Views and Landmarks}

Amman's inhabitants and visitors get lost in the city due to the lack of views and landmarks that could have been located along or seen from its prominent hills and valley corridors, or visible upon entering the city in the direction of the older downtown. The lack of open spaces and formal parks is also a factor. The city needs landmarks, which may be physically or spiritually unique, influential, impressive, and commonly recognized by the people as a sign of place and direction (Hasanuddin, 2004). In the downtown core, there are many individually significant landmarks, like the Great Amphitheater, the Al-Hussein Mosque, and the Nymphaeum. As for the existing hills, they also have a few landmarks that include prominent heritage sites on Al Qalaah Hill (the Citadel), in addition to an extensive network of churches, mosques and minarets on other hills. The latter landmarks melt into the dense residential development zones and include, most prominently, the Abu-Darweesh mosque on Al Ashraffiyyh Hill and the Al Weibdah church on Al Weibdah Hill.

\subsection{Land use and occupancy}

Mixed-use commercial zoning dominates the designated central commercial zone in the downtown core, comprised mainly by the Amphitheater and Citadel sites, with $90 \%$ of residential areas located along the surrounding hills.
The side slopes of Al Akhdar, Al Natheef, Al Ashraffiyyh, Al Taj, and Al Luweibdah hills are defined by their residential use. The public land use on Amman Hill and Al Qalaah Hill is minimal, aside from the Citadel, the Roman Amphitheater, and the Al-Hussein Mosque area, albeit the share of these sites does not exceed $4 \%$ of the total zoning.

The percentage of land occupancy is very high in the downtown and along the surrounding hills. The average share of vacant plots constitutes approximately $20 \%$ of the total land. Al Qalaah Hill has the highest percentage of vacant land, $30 \%$ : due to its historical characteristics, it is not permitted to exploit the surrounding lands.

\subsection{Buildings and physical features}

The morphology and the physical character of the downtown core and its surrounding hills are shaped by its topography, the harmonious terraced residential edges, and the containment. The downtown has an architectural historic value, thanks to the Al-Hussein Mosque area, the Roman Amphitheater, the Citadel, and the fact that it is overlooking the valley. This allows for introducing iconic structures in selected, unrestricted zones to enhance attraction for tourism and inspirit the city. Amman's downtown is identified by its significant architectural style, ranging from the modern to the regional to the neo-traditional, which aims to keep Amman's traditional and culturalheritage. 


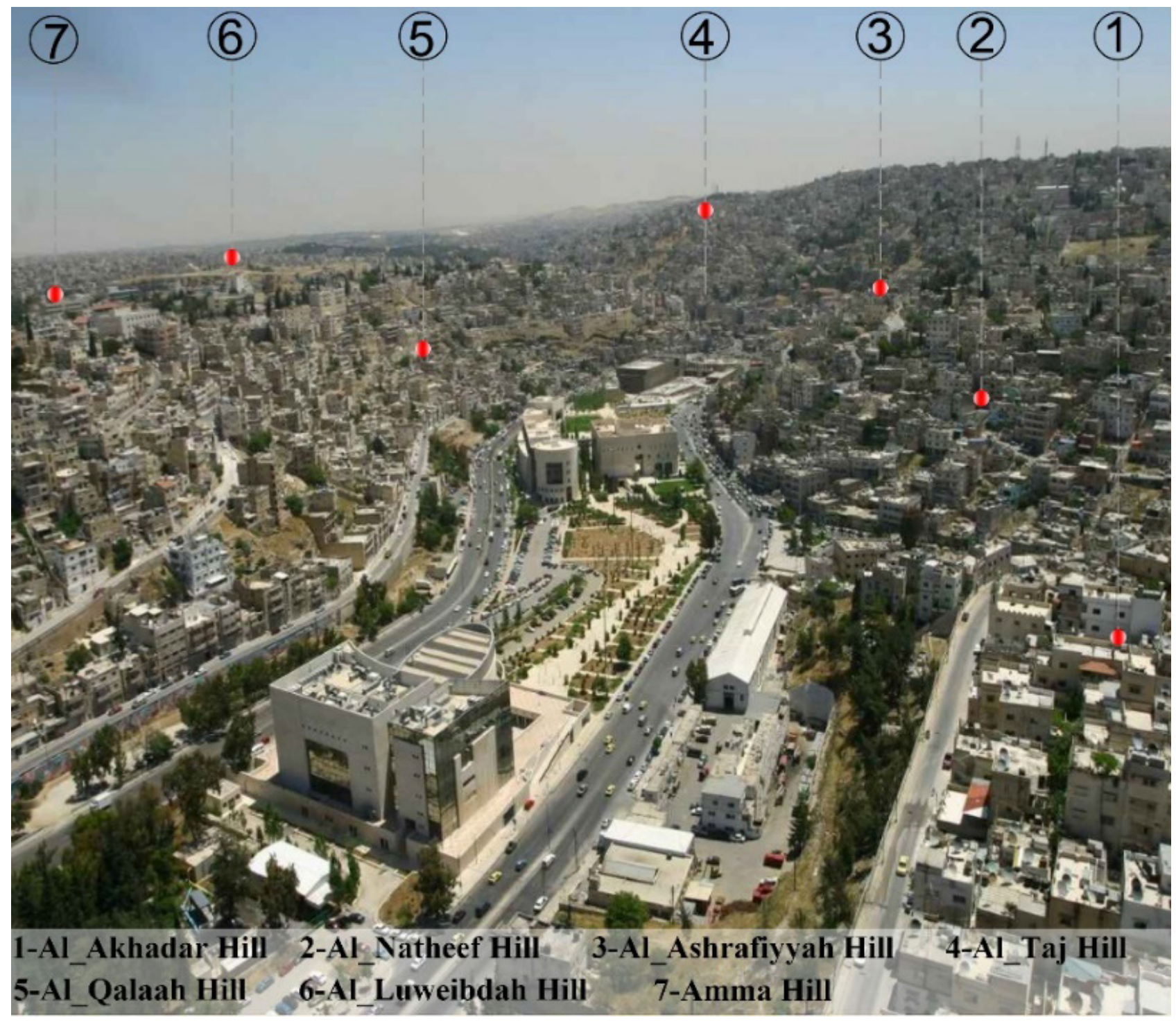

Figure 3. View of the downtown core and the surrounding hills (source: the author)

The buildings are predominantly low-rise, and this height range has remained constant in the downtown over time. Building heights range between 2 and 4 stories, with a few buildings rising to 5-6 stories while not respecting natural gradation and skyline. Residential buildings along the surrounding hills create a harmonious pattern, maintaining open views towards the downtown core. However, many new buildings on the slopes exceed four floors, thanks to the use of additional development rights. If allowed to continue, the construction of such buildings will significantly affect the slope conditions, as well as the image and character of the downtown.

\subsection{Stairway path}

Connections within the downtown core are good, while connections with the surrounding hills are poor. Stairway paths formed spontaneously as a communication element for helping inhabitants reach their homes, and they were not used as an important element in the formation of the urban city plan: they were merely a communication element between the city center and the attractions in open spaces with dominant memorial elements. The downtown is home to many stairways, often hidden from public view. There are more than 600 stairways with at least 75 steps, but previously the downtown had more than 800 total sets of steps in its older parts. The stairs are an integral part of the city's fabric and add to its beauty. Stairways along steep hillsides have been particularly exposed to erosion and pavement cracks over many years.

\subsection{Social characteristics}

In terms of social and cultural characteristics, Amman has been described "as a center of social mix and cultural gathering" (Gharaibeh et al., 2019). "For the first half of the $20^{\text {th }}$ century, Amman neighborhoods were vibrant with diversity, social inclusiveness, and tolerance. People from different socio-economic backgrounds used to frequent the same places" (GAM, 2008). Amman city can be described as a mixture of culturally and socially inclusive areas, where the residents do not form any 
major socioeconomic, religious, or national group. It has sought to accommodate various groups inhabiting the city, including Iraqi nationals; tens of thousands of Egyptian guest workers, almost exclusively young males; other guest workers from Indonesia, the Philippines and Sri Lanka, primarily young women who are employed as domestic help in households; in addition to other minorities in the city, including the descendants of the original Circassians who inhabited Amman during the late $19^{\text {th }}$ century; and Armenians who fled from Turkey during the conflicts of the 1920s (Al-Asad, 1997).

\subsection{Line of sight analysis and 3D projection}

A strategy is needed to regulate the location of the proposed landmark on the seven hills that would be visible from the valley. In recent years, there have been several proposals to develop landmarks, and it is important for a strategy to be put in place in order to control the landmarks' location and design. Global Mapper software offers several tools for qualitative and quantitative analysis of visual impact assessment. Terrain analysis is very useful in this regard. We carried out line of sight analysis to identify the viewing angle and area with the best visibility from the valley, thus determining the potential locations for the proposed landmarks on each hill. Seven sections were selected for each hill, out of the 180 resulting sections (as shown in Fig. 4). We chose those sections that highlight the best topographical features of each hill.

This image displays the area's contour lines and the elevations of the surrounding hills, in addition to the loop section for all hilltops, allowing us to imagine how the physically separated hills can connect visually with each other (see Fig. 5).

The distance for the entire loop is about $8 \mathrm{~km}$, and the average distance between the hilltops is from 1 to $1.5 \mathrm{~km}$. The difference in the hills' terrain and elevation is also evident.

Fig. 6 illustrates the results of the viewshed analysis for the seven hills, where the $X$ axis represents the distance from the valley to the hilltop, while the $Y$ axis represents the elevation of the hill. The visible areas are highlighted in green and the obstructed areas are highlighted in red. The view elevation from different angles ranges from 14 to 32 degrees. We based the line of sight level on the average person's height, which is $2 \mathrm{~m}$ above the sea level. Line of sight analysis in Global Mapper software calculates the visibility along the line of sight from the observer's location in the valley to the target landmark in the hills. Line of sight calculations can be used to visualize any obstructions that may interfere with the view along the profile path. The visible area was determined through the subtraction of the minimum clearance from the maximum clearance, which is based on the intersection of the line of sight path with the terrain surface. The potential locations

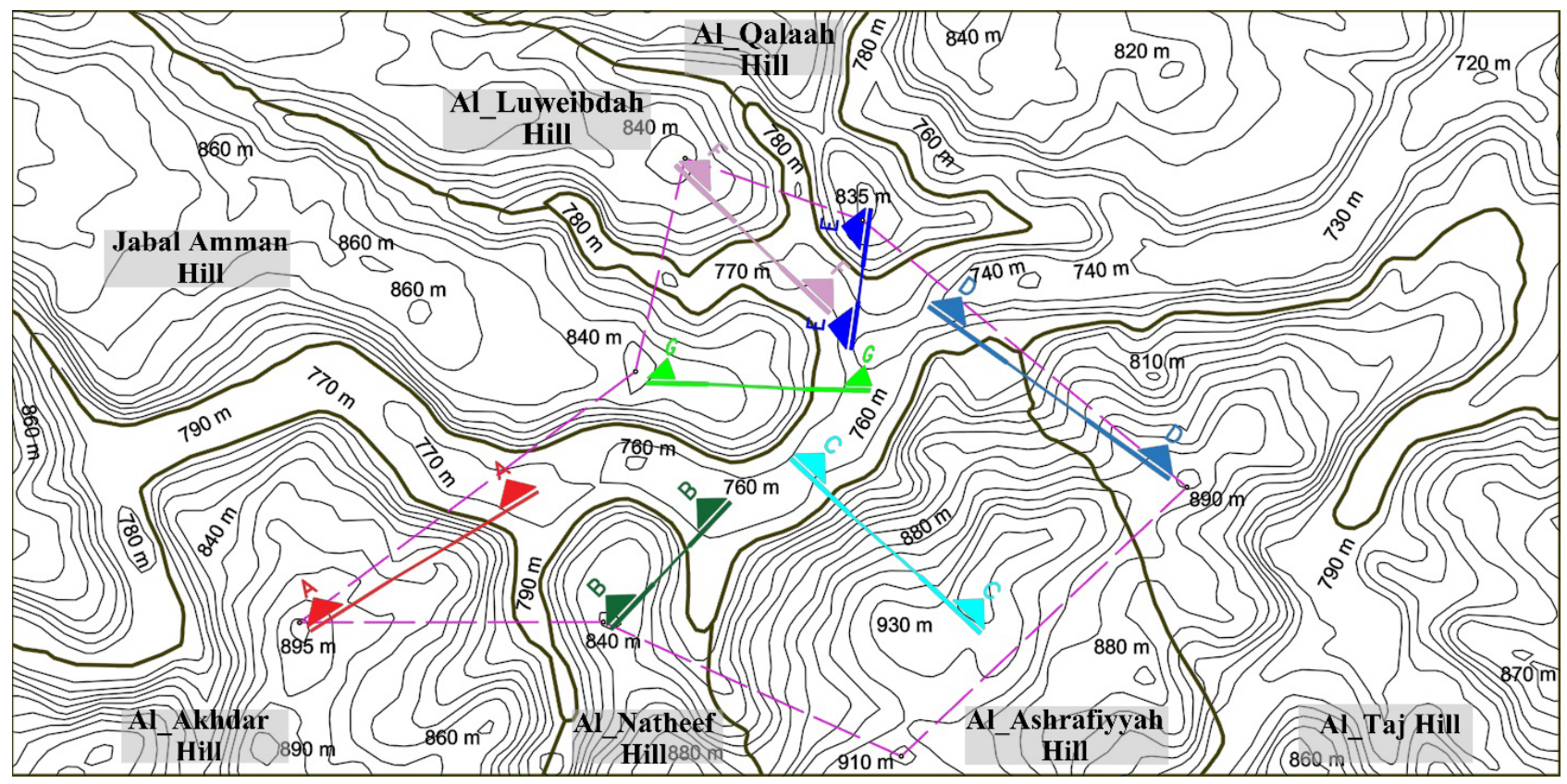

Figure 4. Topographic map of the valley and the hills (source: the author, based on the GIS)

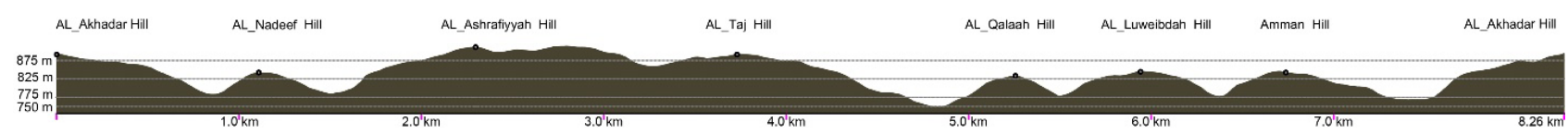

Figure 5. Loop section for the valley and the hills (source: the author, based on the GIS) 

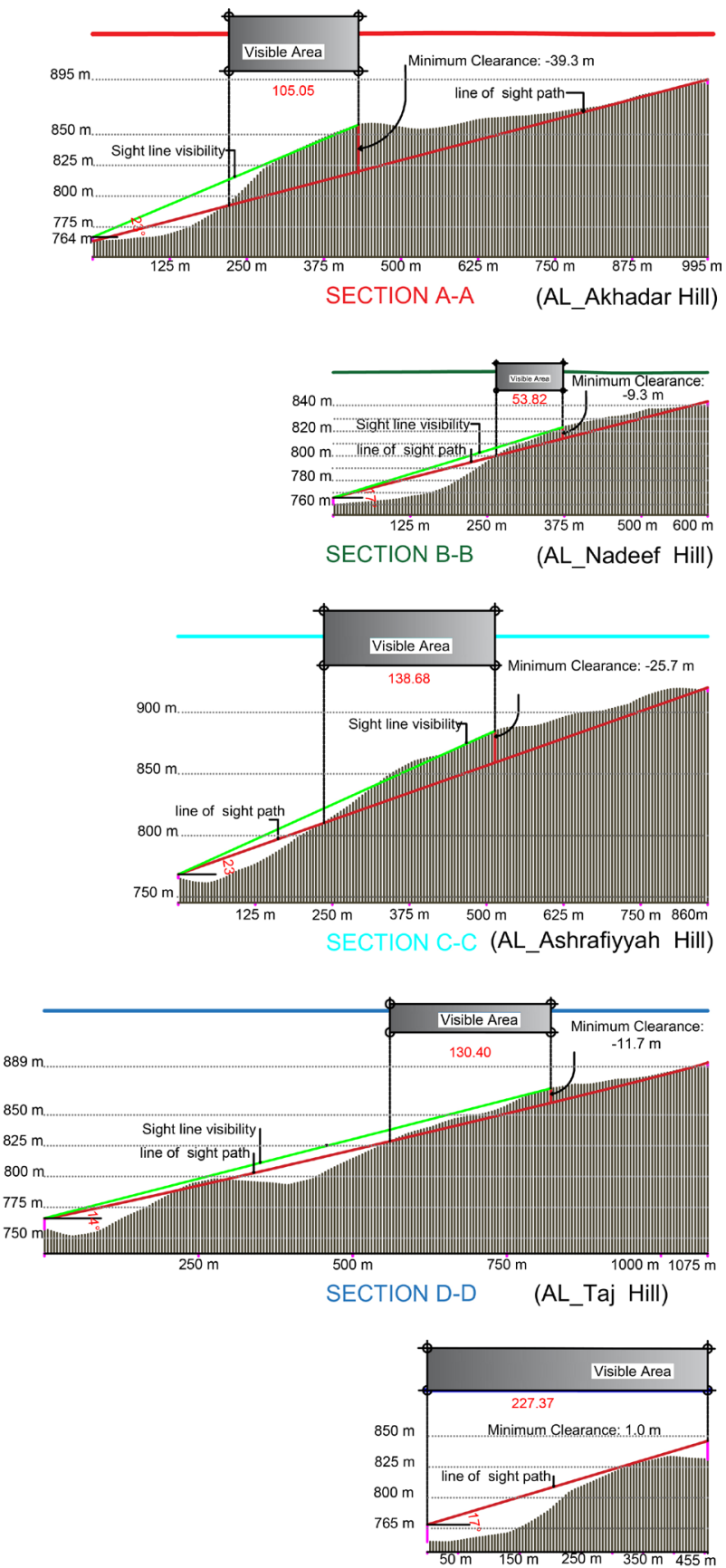

SECTION E-E (AL_Qalaah Hill)
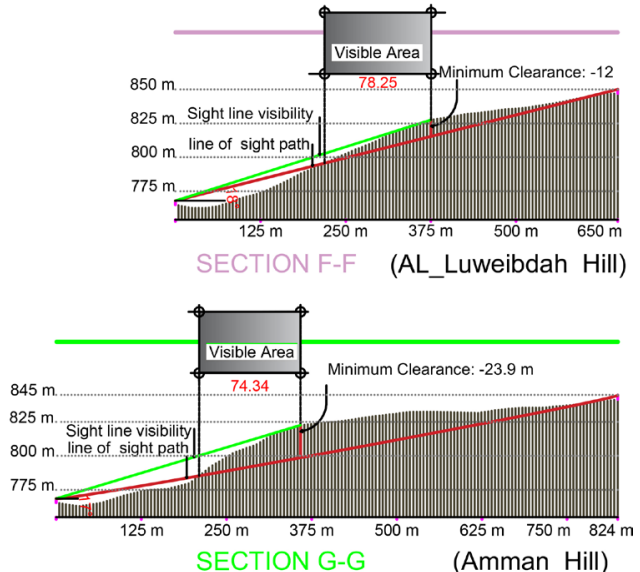

Figure 6. Cross-sections for the seven hills (source: the author, based on the GIS) for the proposed landmarks have been identified depending on the minimum clearance readings. We have found more than one location per hill: some hills have nine locations, and some have five, as shown in Fig. 7. When standing on top of one of the hills, the observer can spot more than one potential vacant site where a landmark could be added. After allocating a few vacant sites for each of the hills, the process of making a 3D projection to select the most appropriate ones would be of prime importance.

As evident in Fig. 6, the degrees of hill slopes vary, ranging from a smooth slope to a steep cliff. The most important feature is that they all have a visible area on the side slope but not at the top, which is unexpected. The only exception is AlQalaah Hill, which is characterized by the greatest visibility when looking from the valley to the hilltop. The existing historic Al-Qalaah Hill is the optimal choice for a landmark visible from the valley, as the field and angle of view are ideal. The viewshed analysis process, aimed at determining the ideal visibility zone for the rest of the hills, highlighted the accuracy and validity of the methodology that we followed.

From this analysis, it is clear that the proposed landmarks' potential locations were well-exposed and consistent with the urban fabric (Fig. 7).

We applied 3D model GIS analysis to identify the vistas, or highly significant views, which will be adopted as a location for the landmarks. The projection process helped define the significant view when looking from the valley to the hills and between the hills. An optimal observation point must be publicly accessible, visible, easy to reach, and with unlimited distance view (Guney et al., 2012). One location has been selected on each hill in accordance with the vacant plots, as shown in Fig. 8. Notably, most of the locations are on the hillside, not on the hilltops, which means that it would be possible to create a picturesque landmark, visible from vantage points and useful when orientating oneself around the downtown (Al Qalaah Hill is an exception, as it already has the Citadel on top).

Table 2 represents the core of the previously mentioned analyses and 3D projections, which reflect the difference in visibility significance, based on topographical differences between the proposed landmarks, as seen when looking from one hill to another and from the valley towards the hills. This table is a good indication of how to maintain open views and connections between the surrounding hills.

\subsection{Scenario-based landmark design}

The need for spatial reference points (landmarks) for each of the seven hills, which have a larger scale than regular residential buildings, would improve the architectural and artistic perception. Landmarks are defined in physical space as having key characteristics that make them a recognizable and memorable part of the environment (Hasanin, 2007). 
Table 2. Visibility significance between the hills (source: the author)

\begin{tabular}{|c|c|c|c|c|c|c|c|}
\hline $\begin{array}{c}\text { Name of } \\
\text { Hill }\end{array}$ & $\begin{array}{c}\text { AL_Akhadar } \\
\text { Hill }\end{array}$ & $\begin{array}{c}\text { AL_Nadeef } \\
\text { Hill }\end{array}$ & $\begin{array}{l}\text { AL_Ashrafiy- } \\
\text {-yah Hill }\end{array}$ & AL_Taj Hill & $\begin{array}{c}\text { AL_Qalaah } \\
\text { Hill }\end{array}$ & \begin{tabular}{|l} 
AL_Luweibd- \\
-ah Hill
\end{tabular} & Amman Hill \\
\hline $\begin{array}{c}\text { AL_Akhadar } \\
\text { Hill }\end{array}$ & & & & & & & \\
\hline $\begin{array}{c}\text { AL_Nadeef } \\
\text { Hill }\end{array}$ & & & & & & & \\
\hline $\begin{array}{c}\text { AL_Ashrafiy- } \\
\text {-yah Hill }\end{array}$ & & & & & & & \\
\hline AL_Taj Hill & & & & & & & \\
\hline $\begin{array}{c}\text { AL_Qalaah } \\
\text { Hill }\end{array}$ & & & & & & & \\
\hline $\begin{array}{l}\text { AL_Luweibd- } \\
\text {-ah Hill } \\
\end{array}$ & & & & & & & \\
\hline Amman Hill & & & & & & & \\
\hline
\end{tabular}

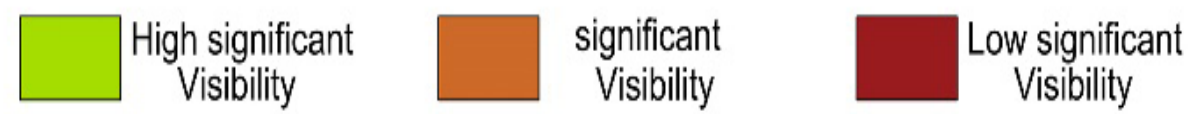

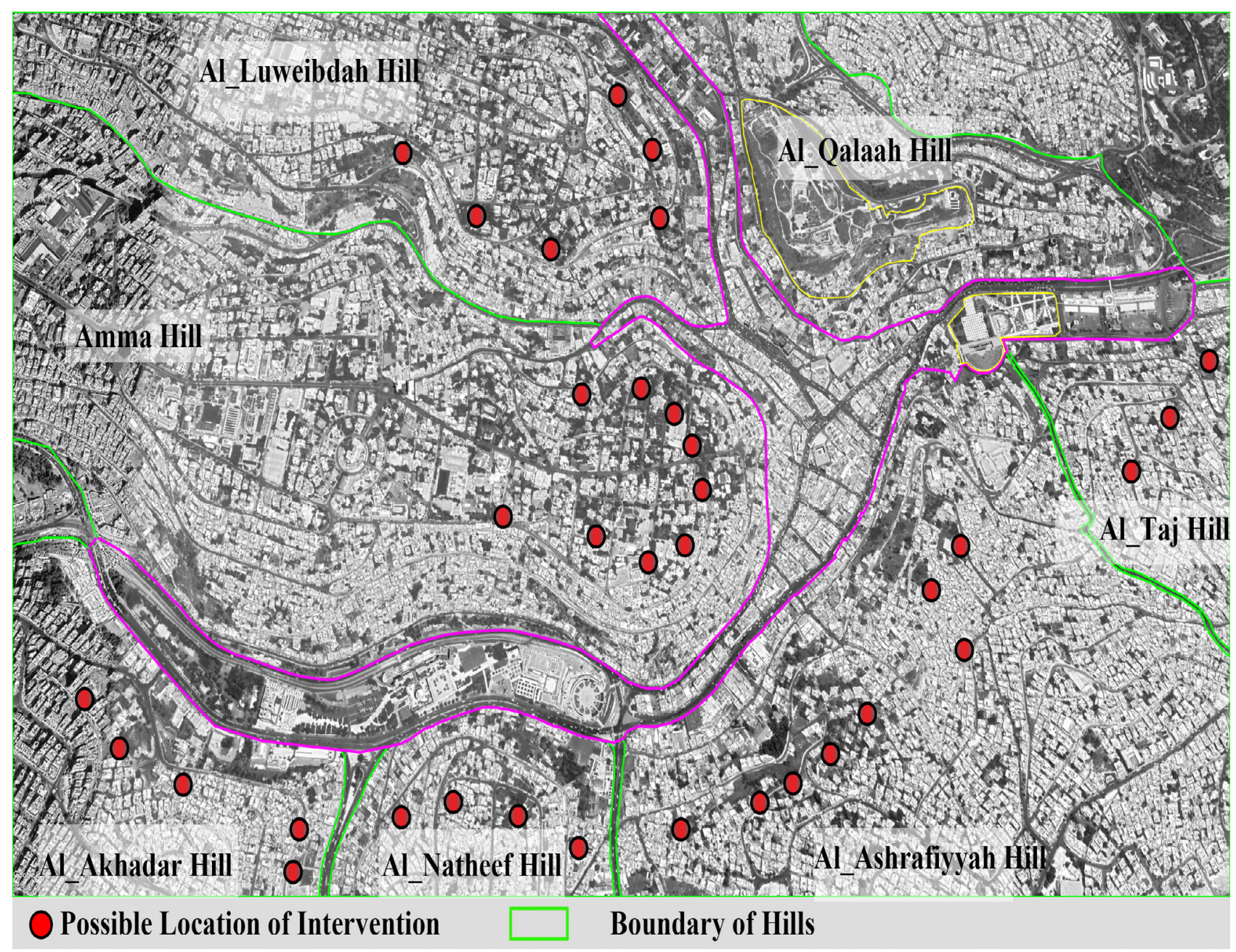

Figure 7. Potential locations for the proposed landmarks (source: the author) 


\section{AL_Taj Hill AL_Ashrafiyyah Hill Amman Hill AL_Nadeef Hill AL_Akhadar Hill}

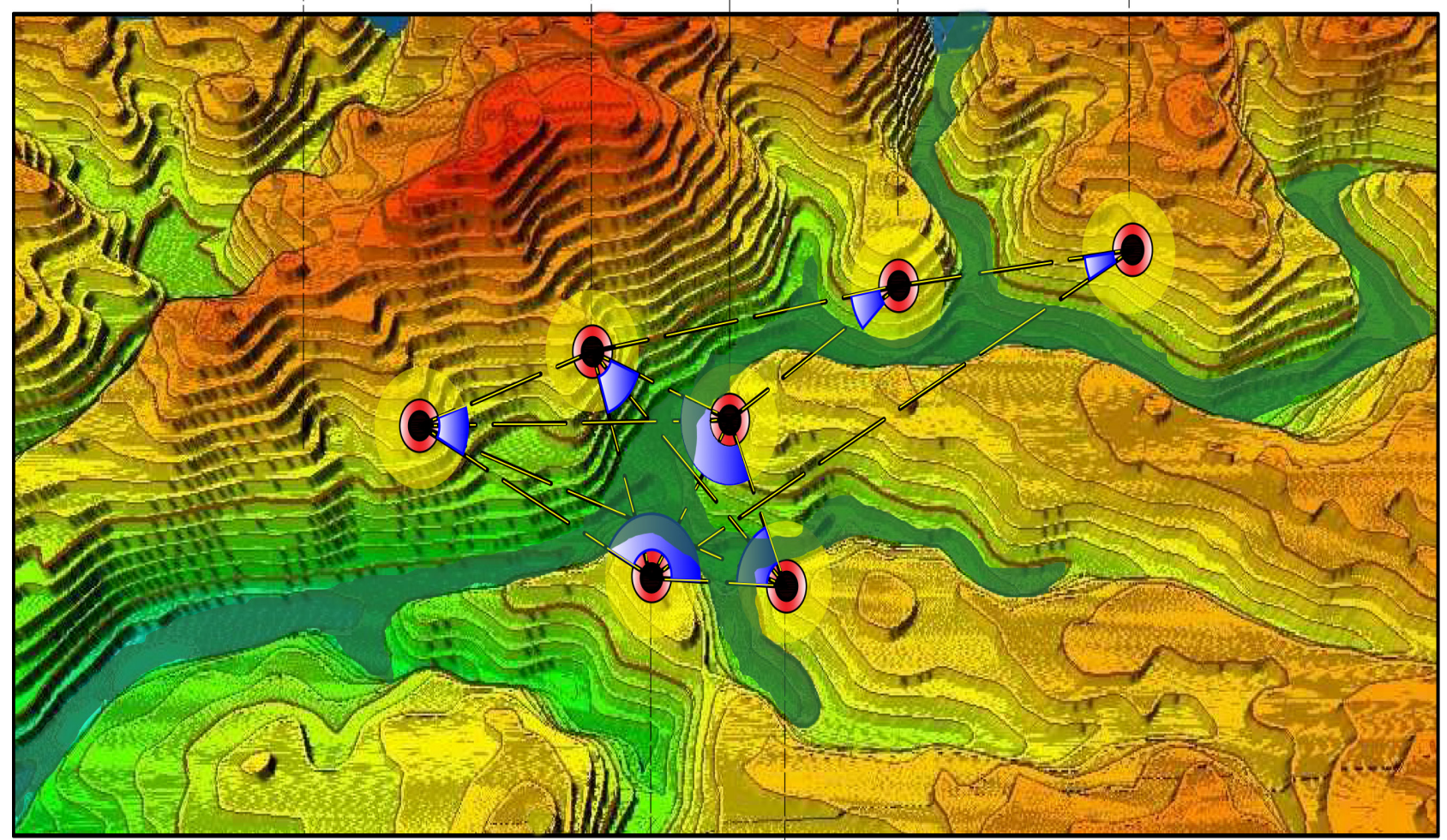

AL_Qalaah Hill

'AL_Luweibdah Hill

$\checkmark$ Significant views degree $\quad-$ Selected locations Visual connections

Figure 8. Visual connectivity between the hills (source: the author, based on the GIS)
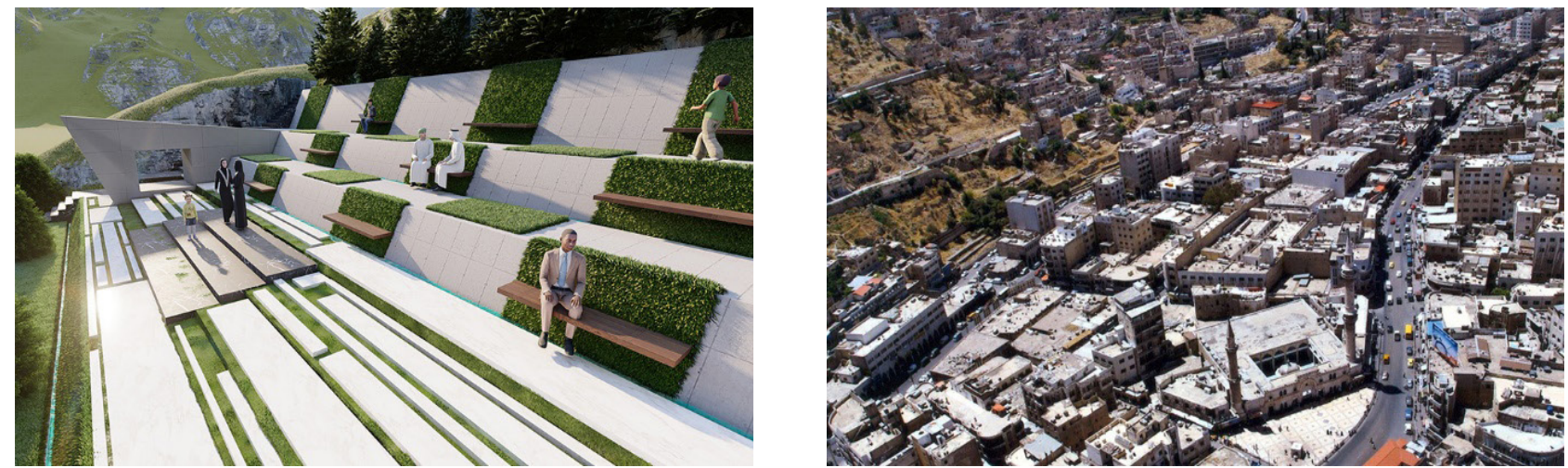

Figure 9. Landscape landmark proposal for Al Ashraffiyyh Hill (source: the author)
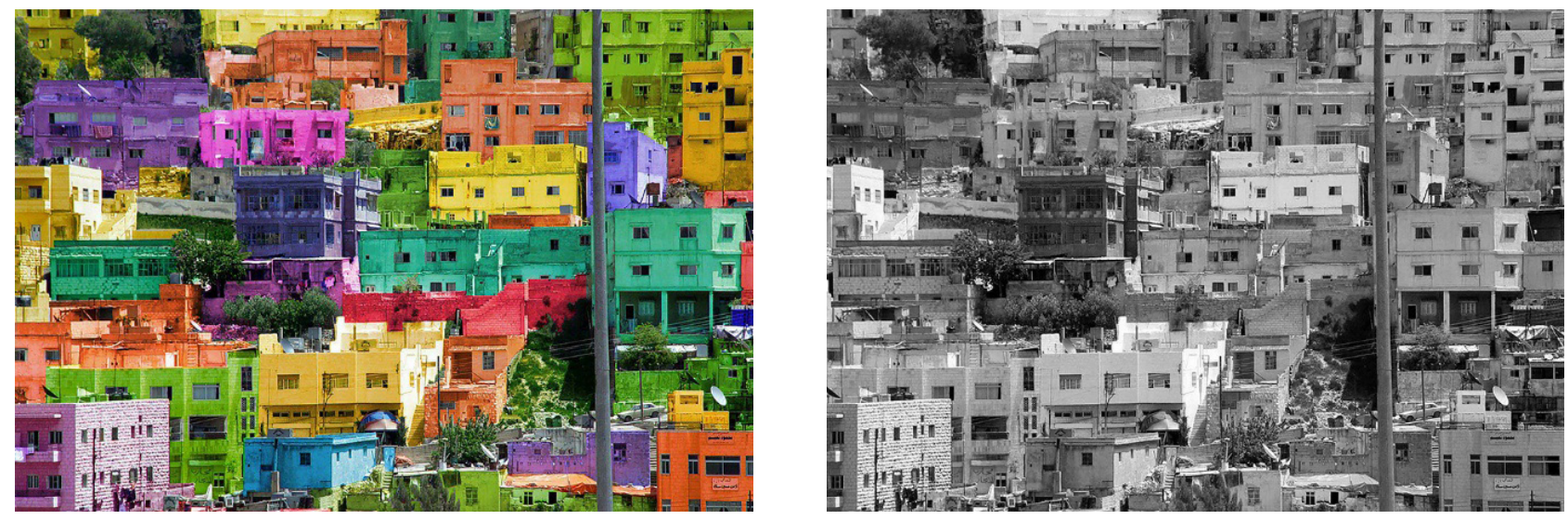

Figure 10. Proposal for a coloristic building landmark on Al Akhadar Hill (source: the author) 
Consequently, each hill needs an expressive image, not only in terms of aesthetics but also as a functional and volumetric component. Landmark design and construction shall rely on the preservation of the current historical part, which implies eliminating the differences between the historical environment and the modern environment by ensuring that they have a similar regular layout, similar proportions, and, mainly, similar scale.

\subsubsection{Scenario 1. Urban ideology approach}

There are many examples of the relationship between ideology and architecture in urban planning. The Seven Sisters, or "Stalin's high-rises", are a group of seven similarly shaped skyscrapers in Moscow, designed in the Stalinist style (socialist ideology) as a symbol of the post-war Soviet Union. Built practically in the center of Moscow, they are visible from almost everywhere throughout the city. Religious buildings, such as mosques, represent this type of approach, for example, the historical city of Istanbul, which is also built upon seven hills and has seven mosques, complex in shape and with various proportions.

The architectural composition of the mosque could be used as a replicable model for the hills, but with different scales, similar to the experience of Istanbul city. This would form a clear visual connection and help distinguish each hill from the others. However, the study of the urban environment contradicts this proposition, given that the vast majority of the hills' territory, $98 \%$ of which is taken up by residential buildings of a monotonous character, is in need of diversity and vitality. The use of such buildings will conflict with the hills' ecological fabric and increase the urban monotony. Furthermore, the center of Amman is characterized by religious, historical, and national diversity, and imposing a single building model will not reflect this diversity.

\subsubsection{Scenario 2. Urban art approach}

Urban art enhances communication between the hills of Amman. It has the potential to create new trails and cultural paths that will develop different spatial qualities along the hill paths. The idea would be to place one attraction point (landmark) on each of the hills, turning it into a magnet for residents from the other hills and creating reverberation and echoes. All together, the magnets would work as a chain that would initiate communication between the hills. The relevant symbolic landmarks could be toys, sculptures, gardens, fountains, etc. Residents and tourists would enjoy going from one hill to another, and experiencing their different characters while contemplating other hills. The symbolic level of environmental quality represents the higher meaning that corresponds to the nature of the occupants, their beliefs and world views; these include such qualities as status or historical value (Hasanin, 2007). These active cultural elements on each of the surrounding hills would give dynamism to the downtown core and connect with each other to create an icon for the city. Despite the effectiveness of this model at the visual and aesthetic level, it does not meet the social and functional needs of the urban environment and the local community. Nonetheless, the use of some of its elements remains possible.

\subsubsection{Scenario 3. Urban theme approach}

The process of knowing the type and function of the proposed dominant architectural element, just as the method of such elements' allocation, should not be spontaneous or coincidental. Rather, they must stem from, and be rooted in, the need to maintain each hill as an urban environment, as well as the characteristics that visually distinguish and complement the hill, as compared to the rest of the hills, to form a functionally integrated coherent ring chain. Thus, each hill needs a special expressive image that would be relevant to it not only in terms of aesthetics but also as a functional and mass component.

Here, the coherent scientific approach lies between achieving both the spiritual, aesthetic, symbolic levels, and the utilitarian functional level, which results in a diverse, attractive, and vibrant urban media environment. By analyzing the topography, architectural planning, and the peculiarities of each hill, we found out how to reach the shape and type of each functionally dominant structure so that it corresponds to the location and merges with it. This scenario was adopted because it meets community needs, as shown in the interviews and in the questionnaire, due to its satisfactory functional and aesthetic solutions.

In this scenario, an architectural proposal organizes landmarks as a visual system of buildings, integrating coloristic, historical, cultural, religious, and landscape features, in accordance with the needs of life and society. The system carries a certain ideological and artistic content, organically combines utilitarian and informational values, as well as general cultural, aesthetic, and figurative artistic values. This project a dynamic, lively, and enjoyable image of the downtown, distinguishing each hill from the others from the residents' and visitors' points of view.

Suggested manipulation was done for some hills as a sample, making it possible to create preliminary visualization of the dominant structures (landmarks).

Al Ashraffiyyh Hill (landscape landmark)

We have mapped out a study of possible future landscape area interventions. Considering the unique topography of the site, as well as the number of undeveloped parcels on steep slopes that are challenging for building construction, new opportunities present themselves for the creation of future gardens that will benefit the inhabitants of the district. The site occupies an important location, overlooking the Citadel, and shall be integrated into the open-space system of the downtown. The proposal is to create landscaped parks and terraced 
courts embedded into the surrounding hill, to be accessible by stairways and footpaths (as displayed in Fig. 9). The exposed slopes, which form an integral part of the surrounding hills, were used as a landmark by creating a formal park overlooking the downtown core, reused as an open public space. Turning these planned spaces into green usable ones will exploit the open space and provide green connections between the surrounding hills and the downtown core.

\section{Al Akhadar Hill (coloristic building landmark)}

This hill's name means "The Green Hill" in Arabic. It is considered the most populous, urban, and chaotic; its buildings do not have any distinctive architectural value. Many residents experience boredom and psychological distress, especially since the urban environment needs to be restructured, and many of these buildings now need a structural re-examination, due to the danger of collapsing. Multiple studies have highlighted the importance of a comprehensive re-examination of this area, strongly encouraging demolition and appropriate redevelopment. It was suggested to make the changes at the lowest financial costs and to find a distinctive, dominant, and expressive landmark consistent with the "Green Hill" name. That can be achieved through the process of re-painting the buildings in a variety of energetic colors, which will affect the community psychologically in a positive way and become a synthetic method. The most chaotic location was chosen for rehabilitation (Fig. 10)

\section{Jabal Amman Hill (multi-purpose landmark)}

Amman Hill is famous for its steep rock cliff. The image of the cliffs between the buildings is something very familiar and commonplace for the residents of Amman Hill. The site for the landmark was chosen between two existing streets, due to the difference in elevation. The proposal was to design a multipurpose building characterized by panoramic views overlooking the downtown core. To complete the image of the buildings surrounding the cliff, stone and glass units were installed and repeated at different distances to embody the concept and break the elevation monotony.

Al Qala'ah Hill (historical landmark)

The new enhancement will represent a responsible new interpretation of Al Qala'ah Hill (the Citadel), taking into consideration both the significance of the context and the needs of the community. This new interpretation of the existing Citadel will be informed by the specificity of the site between the hill (the Citadel) and the valley (the downtown core), including a public open-space framework with several pathways, many markets, walkways, public access points, and a viewing platform, all aimed at enhancing tourist activity.

\section{Conclusion and recommendations}

This research has revealed that an efficient approach is necessary to preserve and sustain the existing landmarks like the Citadel, as well as to create new landmarks in the seven hills to complete the high-end downtown image and identity. In assessing new navigation landmark development proposals, especially for the seven hills forming the topography of the downtown, the local authorities should utilize an array of assessment and decisionmaking support tools. Three landmark navigation scenarios have been demonstrated, out of which the urban theme approach scenario has been adopted, as it meets the needs of the community and reflects the functional and aesthetic values. GIS technologies evidently serve as an efficient tool set that bears significant potential for urban planners and decision-makers. Such technologies can assist with planning, mapping, and managing the new landmarks that are unusual for the specific physical setting, as well as with developing, testing, and evaluating the uniqueness of the downtown image. The analysis performed also carries the imperative potential for future research stages, in terms of the evaluation and enrichment of urban aesthetics visualization, as well as tests of the proposed new landmarks in the hills of Amman.

\section{Acknowledgments}

This research was supported by Applied Science Private University, Faculty of Art and Design. 


\section{References}

Al-Asad, M. (1997). Ruptures in the evolution of the Middle Eastern city. Amman. In: Bonine, M. E. (ed.) Population, Poverty, and Politics in Middle Eastern Cities. Gainesville: University Press of Florida, pp. 46-63.

Ashour, K. (2016). Urban regeneration strategies in Amman's core: Urban development and real estate market. DSc Thesis in Engineering. Dortmund: Dortmund Technical University.

Atik, D. Z., Çakir, H. K. and Benian, E. (2009). The importance of city image elements through recognizing and introducing of cities: Edirne example. Trakia Journal of Sciences, Vol. 7, No. 2, pp. 246-251.

Bostanci, S. H., Ocakçi, M. and Şeker, S. (2006). Kentsel siluetin çeşitlilik açisindan değerlendirilmesinde entropi yaklaşimi. Journal of Istanbul Kültür University, Vol. 2, pp. 83-95.

Clerici, A. and Mironowicz, I. (2009). Are landmarks essential to the city - its development? In: Schrenk, M., Popovich, V. V., Engelke, D., Elisei, P. (eds.) REAL CORP 2009: CITIES 3.0 - Smart, Sustainable, Integrative. Proceedings of $14^{\text {th }}$ International Conference on Urban Planning, Regional Development and Information Society. Schwechat: CORP, pp. 23-32.

ESCWA, 2005. Urbanization and the changing character of the Arab city. New York: Economic and Social Commission for Western Asia, United Nations, $36 \mathrm{p}$.

GAM (Greater Amman Municipality) (2007) Resource Center. Retrieved Dec 6, 2016, from GAM announced fourth phase of master. Plan. [online] Available at: file://C:/Users/RTX/Downloads/ammanplansummaryreport-110129134939-phpapp01.pdf [Date accessed December 6, 2021].

GAM (2008). The Amman Plan Metropolitan Growth. Amman: Greater Amman Municipality.

Gharaibeh, A. A., Al.Zu'bi, E. M. and Abuhassan, L. B. (2019). Amman (City of Waters); Policy, land use, and character changes. Land, Vol. 8, Issue 12, 195. DOI: 10.3390/land8120195.

Guney, C., Akdag Girginkaya, S., Cagdas, G. and Yavuz, S. (2012). Tailoring a geomodel for analyzing an urban skyline. Landscape and Urban Planning, Vol. 105, Issues 1-2, pp. 160-173. DOI: 10.1016/j.landurbplan.2011.12.016.

Hasanin, A. (2007). Urban legibility and shaping the image of Doha: visual analysis of the environmental graphics of the $15^{\text {th }}$ Asian Games. International Journal of Architectural Research, Vol. 1, Issue 3, pp. 37-54. DOI: 10.26687/ archnet-ijar.v1i3.36.

Hasanuddin, L. (2004). Redefining landmarks. Jurnal Alam Bina, Vol. 6, No. 1, pp. 66-76.

Jalouqa, K. (2016). Urban planning of Amman. Amman: Lecture at Jordan Engineers Association.

JICA. (Japan International Cooperation Agency) (2000, August). JICA Library. From Amman Downtown Tourist Zone Sub-project. [online] Available at: https://openjicareport.jica.go.jp/759/759/759_307_11605615.html. [Date accessed April 14, 2020].

Kuala Lumpur City Hall (2008). Draft Kuala Lumpur City Plan 2020. Vol. 1. Kuala Lumpur: Percetakan Nasional Malaysia Berhad.

Lynch, K. (1960). The image of the city. Cambridge, MA: MIT Press, 194 p.

Melnik, V. (2019). Urban identity of Amman (a dialogue between tradition and modernity). Journal of Engineering and Architecture, Vol. 7, No. 1, pp. 68-82. DOI: 10.15640/jea.v7n1a8.

Passini, R. (1992). Wayfinding in architecture. $2^{\text {nd }}$ edition. New York: Van Nostrand Reinhold, 229 p.

Pilder, A. D. (2011). Urbanization and identity: the building of Amman in the twentieth century. MA Thesis in History. Oxford, OH: Miami University.

Potter, R. B., Darmame, K. Barham, N. and Nortcliff, S. (2009). "Ever-growing Amman", Jordan: Urban expansion, social polarisation and contemporary urban planning issues. Habitat International, Vol. 33, Issue 1, pp. 81-92. DOI: 10.1016/j.habitatint.2008.05.005.

Silva, K. D. (2004). Mapping meaning in the city image: towards managing the imageability of urban cultural landscapes. PhD Thesis in Architecture. Milwaukee: The University of Wisconsin.

Zmudzinska-Nowak, M. (2003). Searching for legible city form: Kevin Lynch's theory in contemporary perspective. Journal of Urban Technology, Vol. 10. Issue 3, pp. 19-39. DOI: 10.1080/1063073032000175390. 